\title{
Genetic linkage maps of 'Pêra' sweet orange and 'Cravo' mandarin with RAPD markers
}

\author{
Roberto Pedroso de Oliveira ${ }^{(1)}$, Mariângela Cristofani(2) and Marcos Antônio Machado(2)
}

(1)Embrapa Clima Temperado, Caixa Postal 403, CEP 96001-970 Pelotas, RS. E-mail: rpedroso@cpact.embrapa.br (2)Centro Apta Citros Sylvio Moreira, Caixa Postal 04, CEP 13490-970 Cordeirópolis, SP. E-mail: mariangela@centrodecitricultura.br, marcos@centrodecitricultura.br

\begin{abstract}
The objective of this work was to construct linkage maps of 'Pêra' sweet orange [Citrus sinensis (L.) Osbeck] and 'Cravo' mandarin (Citrus reticulata Blanco) using RAPD markers and the pseudo-testcross strategy. The parents were chosen according to the resistance/susceptibility to citrus variegate chlorosis (CVC). The segregation of 176 markers was analyzed in 94 progeny of $F_{1}$ hybrids, which were obtained from controlled crossings. The linkage map of 'Pêra' sweet orange had 117 markers defined by 12 linkage groups, which spanned $612.1 \mathrm{cM}$. Only six markers could not be linked to the linkage group and $48.7 \%$ of the markers showed segregation distortion. The linkage map of 'Cravo' mandarin had 51 markers defined by 12 linkage groups, which spanned $353.3 \mathrm{cM}$. Only two markers did not link to the groups and $15.7 \%$ showed segregation distortion. The construction of linkage maps is relevant to future mapping studies of the inheritance of CVC, citrus canker and leprosis.
\end{abstract}

Index terms: citrus, dominant markers, molecular markers, segregation, breeding methods.

\section{Mapas genéticos de ligação de laranja 'Pêra' e tangerina 'Cravo' utilizando marcadores RAPD}

\begin{abstract}
Resumo - O objetivo deste trabalho foi elaborar mapas de ligação de laranja 'Pêra' [Citrus sinensis (L.) Osbeck] e tangerina 'Cravo' (Citrus reticulata Blanco) utilizando marcadores RAPD e a estratégia pseudo-testcross. Os parentais foram escolhidos tomando-se por base o nível de resistência/suscetibilidade à clorose variegada dos citros (CVC). A segregação de 176 marcadores foi analisada em uma progênie de 94 híbridos $\mathrm{F}_{1}$, obtidos por meio de cruzamentos controlados. O mapa de ligação de laranja 'Pêra' apresentou 117 marcadores distribuídos em 12 grupos de ligação, totalizando $612,1 \mathrm{cM}$. Apenas seis marcadores não se ligaram a algum dos grupos de ligação e 48,7\% deles apresentaram segregação distorcida. O mapa de ligação de tangerina 'Cravo' apresentou 51 marcadores distribuídos em 12 grupos de ligação, totalizando 353,3 cM. Apenas dois marcadores apresentaram-se desligados e 15,7\% deles apresentaram segregação distorcida. A elaboração de mapas de ligação dessas cultivares é relevante para futuros estudos da herança da resistência à CVC, cancro cítrico e leprose.
\end{abstract}

Termos para indexação: citro, marcador dominante, marcador molecular, segregação, método de melhoramento.

\section{Introduction}

According to Food and Agriculture Organization (FAO, 2002), Brazil is the largest producer of citrus in the world, and 'Pêra' sweet orange (Citrus sinensis (L.) Osbeck) is the variety of highest commercial importance.

Citrus breeding programs present biological limitations due to the heterogeneity of the genus, polyembryonic nature, long reproduction cycle, sterility, incompatibility and endogamy depression. Moreover, the literature does not provide information on the nature and manner of the genetic inheritance of some traits of economic importance (Grosser \& Gmitter Junior, 1990).
Linkage maps are the bases for advanced genetic studies; they allow a better understanding of the inheritance, identification and isolation of the genes. Cloning of genes will be facilitated by well-defined genetic maps in many species.

Some genetic characteristics of citrus as the haploid chromosomes number of 9 , the high polymorphism, the production of fertile interspecific and intergeneric hybrids and the small genome size $(1 \mathrm{C}=0.62 \mathrm{pg})$ favor the construction of linkage maps (Gmitter Junior et al., 1996).

Genetic maps of several species have been developed in the last few years, using different types of molecular markers. RAPD (Random Amplified Polymorphic DNA) markers were widely used for mapping citrus species in 
the past (Jarrell et al., 1992; Roose et al., 1992; Cai et al., 1994; Luro et al., 1994; Gmitter Junior et al., 1996; Simone et al., 1998; Cristofani et al., 1999). These markers are detected by the amplification of genomic DNA fragments of different sizes through the polymerase chain reaction (PCR) using primers of random sequence. The RAPD technique is easy, not very expensive, uses a low concentration of genomic DNA, and produces markers that are highly polymorphic and represent the whole genome (Ferreira \& Grattapaglia, 1998).

There are several studies on citrus with the purpose of mapping genes and quantitative trait loci (QTL) for resistance/susceptibility to mineral salts, cold, "tristeza" virus, juvenile characters and vigor (Roose et al., 1992; Mestre et al., 1997; Cristofani et al., 1999).

'Pêra' sweet orange is highly susceptible to citrus variegated chlorosis (CVC) and 'Cravo' mandarin (Citrus reticulata Blanco) is tolerant (Machado et al., 1993). In Brazil, the annual losses in citrus production due to CVC are estimated to be 235 millions dollars (Fundecitrus, 2000). In Centro Apta Citros 'Sylvio Moreira', São Paulo State, a hybrid progeny between 'Cravo' mandarin and 'Pêra' sweet orange was obtained by controlled crossings (Oliveira et al., 2000). Therefore, that progeny and the genetic maps of 'Pêra' sweet orange and 'Cravo' mandarin may help to understand the inheritance of CVC and other important traits.

The objective of this work was to build linkage maps of 'Pêra' sweet orange and 'Cravo' mandarin, using RAPD markers and the pseudo-testcross strategy.

\section{Material and Methods}

The samples were composed of $94 \mathrm{~F}_{1}$ hybrids between 'Cravo' mandarin ( $C$. reticulata Blanco) and 'Pêra' sweet orange ( $C$. sinensis (L.) Osbeck). Hybrids were originated from controlled crossing, where 'Cravo' mandarin was the female parent. Morphological (petiole, leaves shape and plant vigor) and RAPD markers were used to select the hybrids from the nucellar plants (Oliveira et al., 2000). The zygotic plants were identified using three pair of primers (OPG08, OPG13 and OPG19).

Genomic DNA was extracted from fresh mature leaves using the CTAB method (Murray \& Thompson, 1980). The DNA quantification was performed on agarose gel (1\%) stained with ethidium bromide $\left(0.5 \mathrm{ng} \mathrm{mL}^{-1}\right)$, and compared to non-digested $\lambda$-DNA in

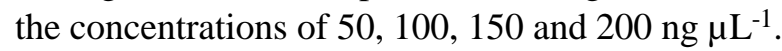

The PCR amplification reactions were prepared in final volume of $13 \mu \mathrm{L}$, with $1.3 \mu \mathrm{L}$ of $10 \mathrm{X}$ buffer (200 mM Tris-HCl, pH 8.4; $500 \mathrm{mM} \mathrm{KCl);} 1.54 \mathrm{mM}$ $\mathrm{MgCl}_{2} ; 0.2 \mathrm{mM}$ of each dNTP (dATP, dCTP, dTTP, dGTP); $15 \mathrm{ng}$ of each primer; 1.5 units of Taq DNA polymerase, and $15 \mathrm{ng}$ of genomic DNA. Aliquot of $20 \mu \mathrm{L}$ of mineral oil was added in each reaction. The amplification reactions were conducted by a thermocycler, programmed for 36 cycles at $92^{\circ} \mathrm{C}$ for $1 \mathrm{~min}$, at $36^{\circ} \mathrm{C}$ for $1 \mathrm{~min}$ and at $72^{\circ} \mathrm{C}$ for $2 \mathrm{~min}$, and a final extension at $72^{\circ} \mathrm{C}$ for $10 \mathrm{~min}$.

Ninety seven decamer primers with random sequence (Operon Technologies Inc.) of the kits A, AB, AT, AV, B, C, D, E, G, H, I, M, N, P, Q, R, U and T were evaluated. Following PCR, aliquots of $5 \mu \mathrm{L}$ of amplification solution with $1 \mu \mathrm{L}$ of tracking dye $(0.25 \%$ bromophenol blue and $40 \%$ sucrose) were analyzed by electrophoresis in $1.4 \%$ agarose gels containing $5 \mu \mathrm{g} \mathrm{mL}^{-1}$ of ethidium bromide. The electrophoresis was conducted at $94 \mathrm{~V}$ for 3 hours in TAE buffer $(0.04 \mathrm{M}$ Tris-Acetate and $1 \mathrm{mM}$ EDTA). The Plus DNA ladder of $1 \mathrm{~kb}$ was used as a molecular marker. The banding profiles were visualized under UV light.

The polymorphic bands observed for the parents were evaluated according to their absence or presence in the progenies considering only the reproducible bands (Figure 1). The parental origin of the marker was also recorded. Two separate data sets were obtained, one for each parent. The null hypothesis from the 1:1 Mendelian segregation was tested for each marker using the $\chi^{2}$ analyses $(\mathrm{p}<0.05$ and $\mathrm{p}<0.01, \mathrm{DF}=1)$. The pseudo testcross strategy was applied to the linkage analyses among the markers, which was performed with the computer program MAPMAKER version 2.0 (Lander et al., 1987). Compiled data were duplicated and recodified to allow the detection of the linkage of the RAPD marker when in repulsion phase (Grattapaglia $\&$ Sederoff, 1994). Initially, the linkage groups were determined by grouping two points, which were arranged by multipoint analyses. These analyses used LOD 4.0, 5.0 and 6.0 and the maximum recombination frequency $(\theta)$ of 0.25 to 0.40 . The Kosambi function was applied to convert the recombination fractions into map distance values of centimorgans (cM). The marker order and the distances between markers were estimated with the commands Multipoint/Compare and Multipoint/Ripple. The linkage groups were sequentially numbered from the highest to the lowest and were constructed with 
markers from both linkage phases. The markers from the coupling phase were identified as ' + ', while those in repulsion as '-'.

\section{Results and Discussion}

The genetic linkage map of 'Pêra' sweet orange had 117 markers defined in 12 linkage groups, which spanned $612.1 \mathrm{cM}$. The distance between adjacent markers varied from 0 to $25.4 \mathrm{cM}$. The linkage map of 'Cravo' mandarin had 51 markers defined in 12 linkage groups, which spanned $353.3 \mathrm{cM}$. The distance between adjacent markers varied from 0 to $25.4 \mathrm{cM}$.

The number of markers observed in the linkage map of 'Pêra' sweet orange was higher when compared to that of 'Cravo' mandarin. It is because 'Pêra' has a higher rate of heterozygosity, according to Oliveira et al. (2002). It has been documented that inferred species from hybrid origin, such as the sweet oranges (C. sinensis), have higher number of polymorphic fragments than the non-hybrid species, such as the mandarins (C. reticulata) (Oliveira et al., 2002).

The length of the linkage maps of 'Pêra' sweet orange and 'Cravo' mandarin was shorter than that observed for other species and hybrids of Citrus. Cai et al. (1994) developed maps of 1,192 cM; Luro et al. (1994) of $1,503 \mathrm{cM}$; Cristofani et al. (1999) of $732 \mathrm{cM}$ and Simone et al. (1998) of $600 \mathrm{cM}$.

According to Liou (1990) and Jarrell et al. (1992), the genome length of Citrus is estimated to be from 1,500 to $1,700 \mathrm{cM}$. Thus, the maps of 'Pêra' sweet orange and 'Cravo' mandarin covered from $40.8 \%$ to $36.0 \%$ and $23.6 \%$ to $20.8 \%$ of Citrus genome. It means that the map of 'Pêra' sweet orange represents only a third of its genome and that of the 'Cravo' mandarin represents only a fourth of its genome.

The size of the linkage groups varied from 5.34 to $101.05 \mathrm{cM}$ for 'Pêra' sweet orange and from 7.50 to $60.72 \mathrm{cM}$ for the 'Cravo' mandarin (Figures 2 and 3). These results correspond to cytological studies conducted by Guerra (1993), who documented that the size of the chromosomes in species of the genus Citrus, including the C. sinensis, is highly variable. Guerra (1993) clustered the Citrus chromosomes in three groups composed by three chromosomes, according to their sizes: large, medium and small, where the chromosome I was approximately three times larger than the chromosome IX.
The number of linkage groups obtained for both species was significantly greater than the haploid chromosome number of the genus Citrus $(\mathrm{n}=9)$, when applying a $\mathrm{LOD}=6.0$ and a frequency of maximum recombination of 0.25 . No change was observed for the number and composition of the linkage groups when LOD was used between 4 and 6 and frequency of maximum recombination of 0.25 to 0.40. Cai et al. (1994), Luro et al. (1994) and Simone et al. (1998) documented a high number of linkage groups when using LOD between 3 and 5. According to Cristofani et al. (1999), the number of linkage groups can be equal to the haploid chromosome number if new markers are introduced into the map, thus joining some of the existing linkage groups.

Studies on genetic linkage maps have reported a distortion in a Mendelian type segregation of markers in several levels, from intraspecific to intergeneric hybridizations, with levels between 3.9\% (Grattapaglia \& Sederoff, 1994) and 100\% (Nienhuis et al., 1987). In this work, $61.5 \%(\mathrm{p}<0.05)$ of the markers showed segregation distortion in the 'Pêra' sweet orange and

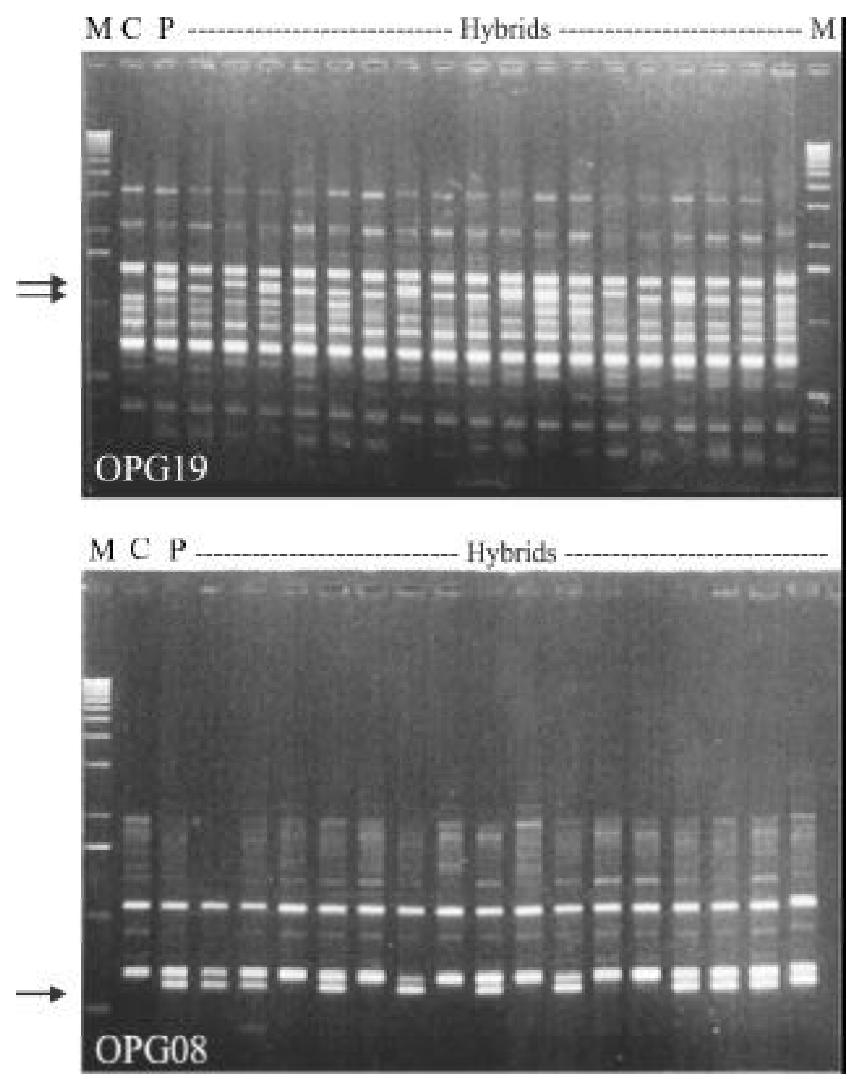

Figure 1. PCR amplification with primers OPG19 and OPG08. M: marker of $1 \mathrm{~kb}$; C: 'Cravo' mandarin (Citrus reticulata Blanco); and P: 'Pêra' sweet orange [Citrus sinensis (L.) Osbeck]. Markers are indicated by the arrows. 


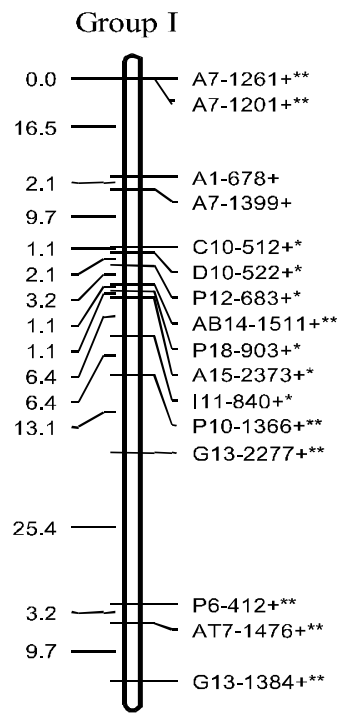

$101,05 \mathrm{cM}$

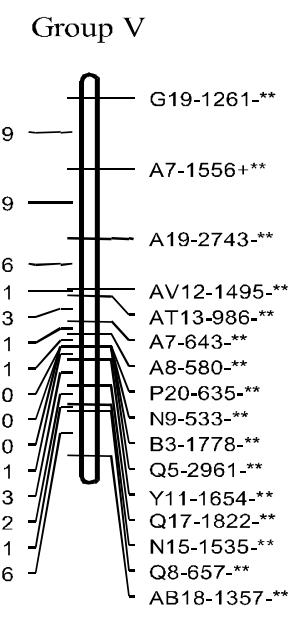

$60.27 \mathrm{cM}$

\section{Group IX}

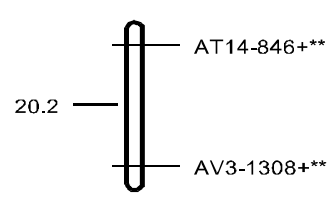

$20.18 \mathrm{cM}$

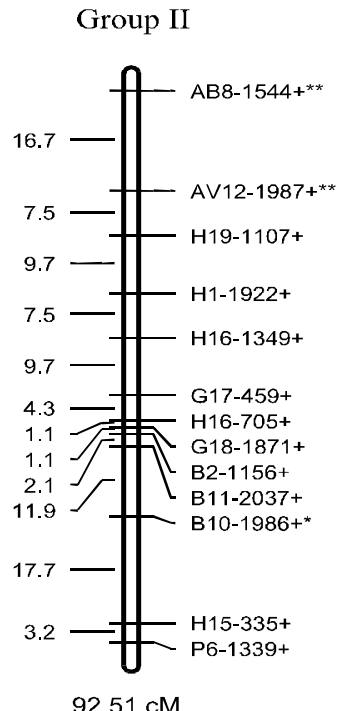

Group VI

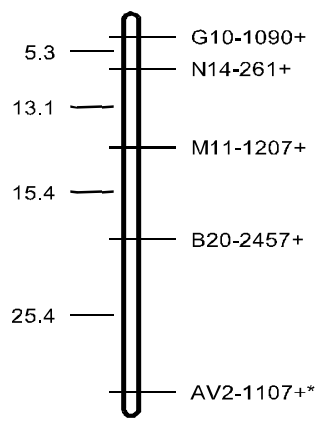

$59.22 \mathrm{cM}$
Group III

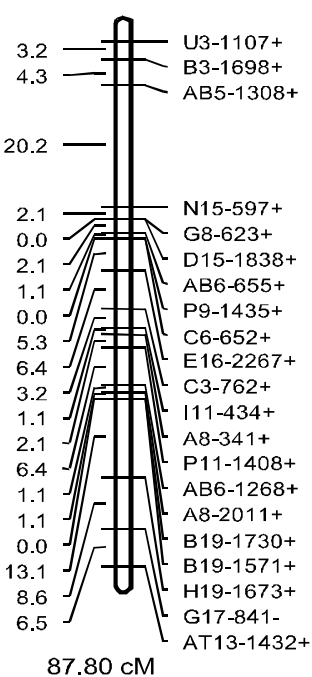

$87.80 \mathrm{cM}$
Group IV

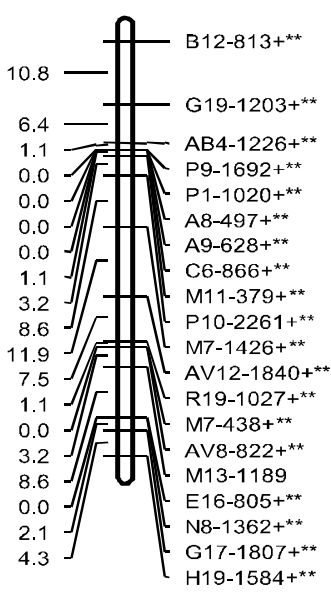

$69.82 \mathrm{cM}$

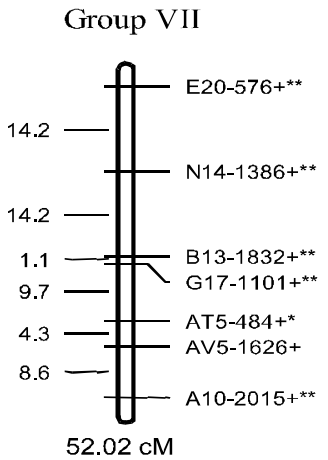

Group XI

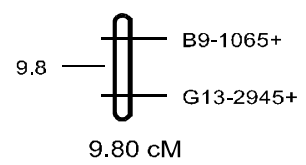

Group VIII

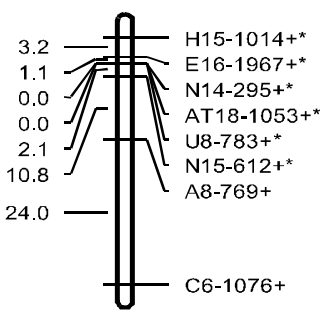

$41.23 \mathrm{cM}$
Group X

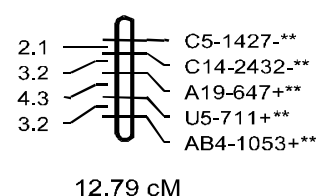

$12.79 \mathrm{cM}$

\section{Group XII}

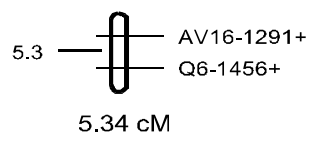

Figure 2. Genetic linkage map of 'Pêra' sweet orange [C. sinensis (L.) Osbeck] showing linkage relationships of 117 RAPD markers established at a threshold LOD $\geq 6.0$ and $\theta \leq 0.25$. RAPD marker loci are identified by the operon primer code, fragment size and linkage phase (+ or -). RAPD marker loci showing significant distortion from 1:1 segregation ratio is indicated by one asterisk $(\mathrm{p}<0.05)$ and two asterisks $(\mathrm{p}<0.01)$. 
$25.5 \%(\mathrm{p}<0.05)$ in 'Cravo' mandarin. A 1:1 proportion as expected for the pseudo-testcross configuration was used, since it was hypothesized that the dominant markers were in heterozygosity for one of the parents (Aa) and in homozygosity for the other parent (aa). High levels of deviations were observed in several crossings involving the genus Citrus, independently of the species and the type of marker used (Durham et al., 1992; Jarrell et al., 1992; Cai et al., 1994; Luro et al., 1994; Kijas et al., 1997). There is a high genetic similarity between 'Pêra' sweet orange and 'Cravo' mandarin (Oliveira et al., 2002), even though the levels of distortion observed in
Group I

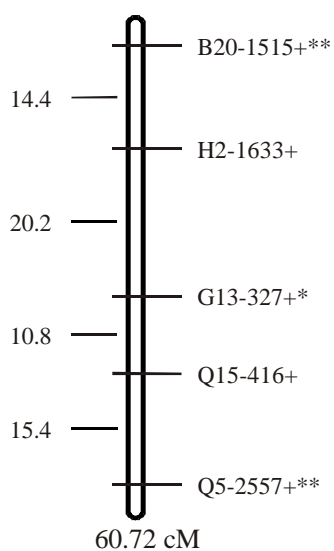

Group V

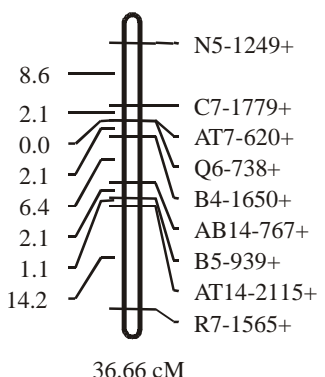

Group IX

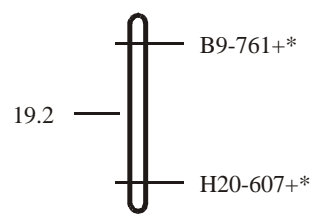

$19.17 \mathrm{cM}$
Group II

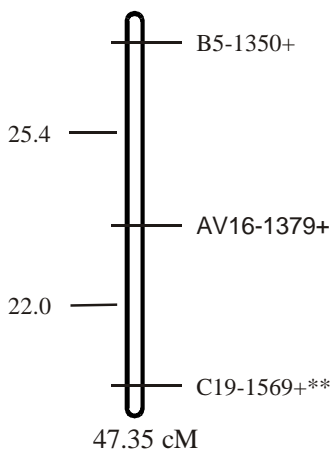

Group VI

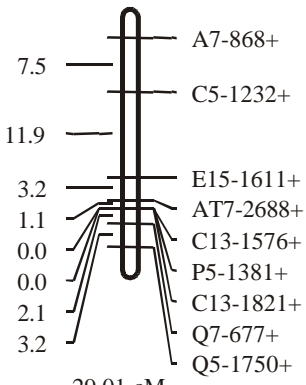

$29.01 \mathrm{cM}$

Group X

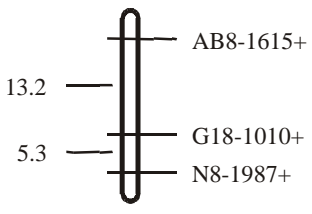

$18.54 \mathrm{cM}$
Group III

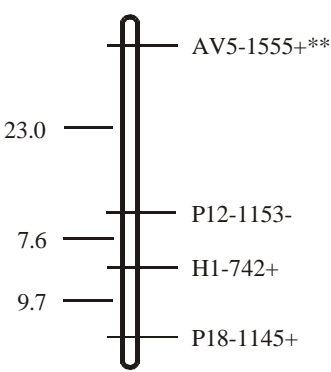

$40.28 \mathrm{cM}$
Group IV

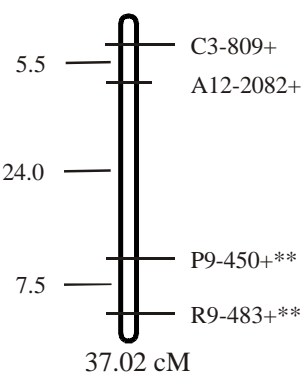

Group VIII

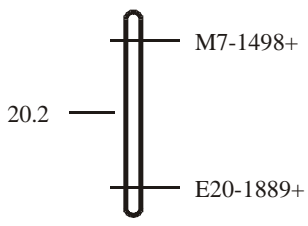

$20.18 \mathrm{cM}$

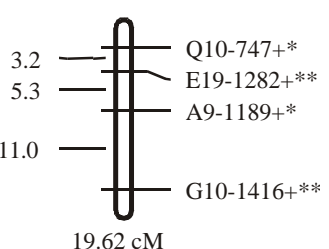

Group XII

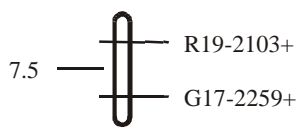

$7.50 \mathrm{cM}$

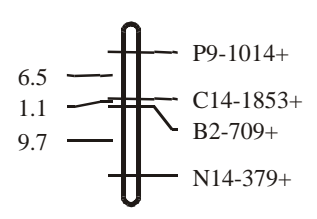

$17.25 \mathrm{cM}$

Figure 3. Genetic linkage map of 'Cravo' mandarin (C. reticulata Blanco) showing linkage relationships of 51 RAPD markers established at a threshold LOD $\geq 6.0$ and $\theta \leq 0.25$. RAPD marker loci are identified by the operon primer code, fragment size and linkage phase (+ or -). RAPD marker loci showing significant distortion from 1:1 segregation ratio is indicated by one asterisk $(\mathrm{p}<0.05)$ and two asterisks $(\mathrm{p}<0.01)$. 
the segregation were similar to those of intergeneric crossings.

In this work, the distortion observed in the expected Mendelian segregation can be related to a few biological causes, because the level observed was statistically significant. The highly heterozygous structure of the parents, especially that from the 'Pêra' sweet orange, might have an important role in the frequency of distortion. This is due to deleterious recessive alleles kept in heterozygous form of the parents and in homozygous form of some hybrids. The lost of hybrids should explain the high segregation distortion rate in both parents.

The markers that showed segregation distortion were also used in the mapping analyses of the 'Pêra' sweet orange and 'Cravo' mandarin like the maps constructed by Cai et al. (1994), Luro et al. (1994), Simone et al. (1998) and Cristofani et al. (1999). This procedure was applied because these loci provide important genetic information to the maps, even though they can strongly affect the calculation of the genetic distance among the markers as well as their location in the linkage group (Jarrell et al., 1992).

The markers with segregation distortion that grouped in a few linkage groups, especially in groups I, IV, V, VII, VIII, IX and X of 'Pêra' sweet orange and VIII and IX of 'Cravo' mandarin are shown in Figures 2 and 3. These results corroborate those reported by Jarrell et al. (1992), Cai et al. (1994) and Luro et al. (1994). Moreover, Cristofani et al. (1999) observed that $34 \%$ of the loci with segregation distortion grouped in the linkage group IV of 'Rubidoux' and 55\% grouped in the linkage group III in the map of 'Sunki'. Therefore, genes and/or the QTL of interest might not be easily located.

This study showed that only $4.6 \%$ of the markers did not link to any linkage groups, and this result is similar to maps that are moderately saturated such as those of Eucalyptus (4.5\%) (Grattapaglia \& Sederoff, 1994) and apple (4.6\%) (Hemmat et al., 1994). Data collected by Cai et al. (1994), Simone et al. (1998) and Cristofani et al. (1999) from crossings that involved the genus Citrus revealed that $28.9 \%, 26.8 \%$ and $10.3 \%$ of markers did not link to any linkage groups, respectively.

The linkage groups I, II, III, IV, V and VIII of the 'Pêra' sweet orange map and the linkage groups $\mathrm{V}$ e VI of 'Cravo' mandarin map showed the formation of the RAPD marker clusters (Figures 2 and 3). Likewise, Grattapaglia \& Sederoff (1994) and Simone et al. (1998) observed the same tendency when working with dominant markers, especially while increasing the level of saturation of the maps. These authors also reported that this fact occurred independently of the type of the molecular marker and of the organism used. Tanksley et al. (1992) showed that the formation of groups of markers can have a biological basis, which is related to a low occurrence of the genetic recombination in the heterochromatin next to centromeres and/or in the telomeric regions. Since the chromosomes of Citrus have large quantity of heterochromatin (Guerra, 1993), the tendency of forming groups of markers appears to be even higher when compared to other genera. Moreover, Guerra (1993) documented that the quantity of heterochromatin is variable in each Citrus chromosome and this fact can explain the preferential formation of groups of markers.

Research conducted by Oliveira et al. (2002), based on RAPD data, describes high genetic similarity between the parents 'Pêra' sweet orange and 'Cravo' mandarin (77.2\%). This can be explained, because $C$. reticulata is attributed as an ancestor parent of $C$. sinensis (Federici et al., 1998). Consequently, the RAPD polymorphism was considered lower than that obtained from intergeneric crossings (Cristofani et al., 1999), thus making it difficult to obtain markers. However, in addition to the 176 markers used during the mapping, 80 RAPD bands were found in simultaneous heterozygosis in the parents. These markers were not used in the present maps because they had a different type of segregation, which could not be used in an integrated map of Citrus with the computer program MAPMAKER.

\section{Conclusions}

1. The first genetic linkage maps of 'Pêra' sweet orange and 'Cravo' mandarin show high percentage of markers with segregation distortion, which concentrated in some linkage groups.

2. The linkage groups of 'Pêra' sweet orange and 'Cravo' mandarin show the formation of RAPD marker clusters.

\section{Acknowledgements}

To Conselho Nacional de Desenvolvimento Científico e Tecnológico $(\mathrm{CNPq})$ for the financial support. 


\section{References}

CAI, Q.; GUY, C.L.; MOORE, G.A. Extension of the linkage map in Citrus using random amplified polymorphic DNA (RAPD) markers and RFLP mapping of cold-acclimation-responsive loci. Theoretical and Applied Genetics, v.89, p.606-614, 1994.

CRISTOFANI, M.; MACHADO, M.A.; GRATTAPAGLIA, D. Genetic linkage maps of Citrus sunki Hort. ex.Tan. and Poncirus trifoliata (L.) Raf. and mapping of citrus tristeza virus resistance gene. Euphytica, v.109, p.25-32, 1999.

DURHAM, R.E.; LIOU, P.C.; GMITTER JUNIOR, F.G.; MOORE, G.A. Linkage of restriction fragment length polymorphisms and isozymes in Citrus. Theoretical and Applied Genetics, v.84, p.3948, 1992.

FAO (Rome, Italy). Quarterly bulletins of statistics. Rome, 2002. Available at: <http://apps.fao.org/cgi-bin/aphdb.pl?subset=agriculture $>$. Accessed on: Oct. 2002.

FEDERICI, C.T.; FANG, D.Q.; SCORA, R.W.; ROOSE, M.L. Phylogenetic relationships within the genus Citrus (Rutaceae) and related genera as revealed by RFLP and RAPD analyses. Theoretical and Applied Genetics, v.96, p.812-822, 1998.

FERREIRA, M.E.; GRATTAPAGLIA, D. Introdução ao uso de marcadores moleculares em análise genética. 3.ed. Brasília: Embrapa-Cenargen, 1998. 220p.

FUNDECITRUS. CVC: sintomas estão mais graves. Revista do Fundecitrus, v.99, p.8-9, 2000.

GMITTER JUNIOR, F.G.; XIAO, S.Y.; HUANG, S.; HU, X.L.; GARNSEY, S.M.; DENG, Z. A localized linkage map of the virus tristeza virus resistance gene region. Theoretical and Applied Genetics, v.92, p.688-695, 1996.

GRATTAPAGLIA, D.; SEDEROFF, R. Genetic linkage maps of Eucalyptus grandis and Eucalyptus urophylla using a pseudo-testcross: mapping strategy and RAPD markers. Genetics, v.137, p.1121-1137, 1994.

GROSSER, J.W.; GMITTER JUNIOR, F.G. Somatic hybridization of Citrus with wild relatives for germplasm enhancement and cultivar development. HortScience, v.25, p.147-151, 1990.

GUERRA, M.S. Cytogenetics of Rutaceae - V:high chromosomal variability in Citrus species revealed by CMA/DAPI staining. Heredity, v.71, p.234-241, 1993.

HEMMAT, M.; WEEDEN, N.F.; MANGANARIS, A.G.; LAWSON, D.M. Molecular marker linkage map for apple. Journal of Heredity, v.85, p.4-11, 1994.

JARRELL, D.C.; ROOSE, M.L.; TRAUGH, S.N.; KUPPER, R.S. A genetic map of citrus based on the segregation of isozymes and RFLPs in an intergeneric cross. Theoretical and Applied Genetics, v.84, p.49-56, 1992.

KIJAS, J.M.H.; THOMAS, M.R.; FOWLER, J.C.S.; ROOSE, M.L. Integration of trinucleotide microsatellites into a linkage map of Citrus. Theoretical and Applied Genetics, v.94, p.701-706, 1997.
LANDER, E.S.; GREEN, P.; ABRAHAMSON, J.; BARLOW, A.; DALY, M.J.; LINCOLN, S.E.; NEWBURG, L. Mapmaker: aninteractive computer package for constructing primary genetic linkage maps of experimental and natural populations. Genomics, v.1, p.174-181, 1987.

LIOU, P.C. A molecular study of citrus genome through restriction fragment length polymorphism and isozyme mapping. 1990. 143p. Thesis (Ph.D.) - University of Florida, Gainesville.

LURO, F.; LORIEUX, M.; LAIGRET, F.; BOVÉ, J.M.; OLLITRAULT, P. Genetic mapping of an intergeneric Citrus hybrid using molecular markers. Fruits, v.49, p.404-408, 1994.

MACHADO, M.A.; SILVERIO, J.L.; BAPTISTA, C.R.; LARANJEIRA, F.F.; BERETTA, M.J.G. Avaliação de transmissão e seleção de variedades à clorose variegada dos citros. Laranja, v.14, p.167-176, 1993.

MESTRE, P.F.; ASINS, M.J.; PINA, J.A.; CARBONELL, E.A.; NAVARRO, L. Molecular markers flanking citrus tristeza virus resistance gene from Poncirus trifoliata (L.) Raf. Theoretical and Applied Genetics, v.94, p.458-464, 1997.

MURRAY, M.G.; THOMPSON, W.F. Rapid isolation of high molecular weight plant DNA. Nucleic Acids Research, v.8, p.43214325, 1980.

NIENHUIS, J.; HELENTJARIS, T.; SLOCUM, M.; RUGGERO, B.; SCHAEFER, A. Restriction fragment length polymorphism analysis of loci associated with insect resistance in tomato. Crop Science, v.27, p.797-803, 1987.

OLIVEIRA, R.P.; CRISTOFANI, M.; VILDOSO, C.I.A.; MACHADO, M.A. Diversidade genética entre híbridos de tangerina 'Cravo' e laranja 'Pêra' utilizando marcadores RAPD. Pesquisa Agropecuária Brasileira, v.37, p.479-484, 2002.

OLIVEIRA, R.P.; NOVELLI, V.N.; MACHADO, M.A. Freqüência de híbridos em cruzamento entre tangerina 'Cravo' e laranja 'Pêra': análise de marcadores morfológicos e RAPD. Pesquisa Agropecuária Brasileira, v.35, p.1895-1903, 2000.

ROOSE, M.L.; JARRELL, D.C.; KUPPER, R.S. Genetic mapping in a Citrus $\mathrm{x}$ Poncirus $\mathrm{F}_{2}$ population. Proceedings of the International Society for Citriculture, v.7, p.210-213, 1992.

SIMONE, M.D.; RUSSO, M.P.; PULEO, G.; MARSAN, P.A.; LORENZONI, C.; MAROCCO, A.; RECUPERO, G.R. Construction of genetic maps for Citrus aurantium and C. latipes based on AFLP, RAPD and RFLP markers. Fruits, v.53, p.383-390, 1998.

TANKSLEY, S.D.; GANAL, M.W.; PRINCE, J.P.; VICENTE, M.C.; BONIERBALE, M.W.; BROUN, P.; FULTON, T.M.; GIOVANNONI, J.J.; GRANDILLO, S.; MARTIN, G.B.; MESSEGUER, R.; MILLER, J.C.; MILLER, L.; PATERSON, A.H.; PINEDA, O.; RODER, M.S.; WING, R.A.; WU, W.; YOUNG, N.D. High density molecular linkage maps of the tomato and potato genomes. Genetics, v.132, p.1141-1160, 1992. 